\title{
Pra Desain Pabrik Bioetanol dari Limbah Batang Sorgum Difermentasikan dengan Kluyveromyces marxianus
}

\author{
Irham Raditya Putra, Yumna Dian Pawitra, Sri Rachmania Juliastuti, dan Nuniek Hendrianie \\ Departemen Teknik Kimia, Fakultas Teknologi Industri, Institut Teknologi Sepuluh Nopember (ITS) \\ Jl. Arief Rahman Hakim, Surabaya 60111 Indonesia \\ e-mail: juliaz30@chem-eng.its.ac.id dan nuniek@chem-eng.its.ac.id
}

\begin{abstract}
Abstrak-Pencemaran lingkungan dan krisis energi kini sudah menjadi topik hampir di semua kalangan. Karena hampir semua penggunaan energi menggunakan bahan bakar fosil yang memiliki dampak buruk bagi lingkungan sekitar. Dimana hal tersebut terdapat di hasil pembuangan dan pembakarannya yang sangat berbahaya, salah satunya karbon dioksida $\left(\mathrm{CO}_{2}\right)$. Tetapi dengan meningkatnya karbon dioksida $\left(\mathrm{CO}_{2}\right)$ kini dapat dikurangi dengan menggunakan beberapa metode dengan bahan baku yang tergolong ramah lingkungan untuk mendapatkan bahan bakar alternatif yang ramah lingkungan seperti bioetanol. Salah satunya menggunakan limbah batang sorgum, karena kadar glukosa yang cukup tinggi. Bioetanol dapat diperoleh dengan proses fermentasi dengan bantuan mikroorganisme. Pra desain pabrik bioetanol dari limbah batang sorgum ini menggunakan tahapan proses pre-treatment, hidrolisis, fermentasi dan pemurnian. Adapun mikroorganisme yang digunakan adalah Kluyveromyces marxianus. Mikroorganisme ini termasuk anaerob dan menghasilkan etanol dan karbon dioksida. Konsumsi premium pada 2018 diperkirakan sebanyak 62.774.588 kL/tahun. Proses pembuatan bioetanol ini berlangsung secara batch, 24jam/hari dan 330 hari/tahun dengan perencanaan sebagai berikut, Kapasitas produksi : $3.044 .462 \mathrm{~kL} / \mathrm{tahun}$, Bahan baku : $3430 \mathrm{~kg} / \mathrm{jam}$. Pabrik bioetanol ini akan didirikan di Kabupaten Belu, Nusa Tenggara Timur pada tahun 2018. Berdasarkan analisa ekonomi yang dilakukan, diperoleh hasil sebagai berikut : Internal Rate of Return : $10 \%$ per tahun, Pay Out Time : 1,45 tahun, dan BEP : 42,17\%
\end{abstract}

Kata Kunci-bioetanol, fermentasi, sorgum

\section{PENDAHULUAN}

A DANYA Adanya krisis energi, pencemaran udara dan semakin berkurangnya cadangan bahan bakar minyak, maka peluang pemanfaatan bioenergi semakin besar. Dimana bahan bakar alternatif yang ramah lingkungan salah satunya yaitu bioetanol

Bioetanol adalah cairan tidak berwarna yang dapat dihasilkan dengan fermentasi oleh hampir semua sumber gula atau pati, sumber yang paling umum adalah tebu, jagung, gandum dan sorgum. Selulosa biomassa juga dapat digunakan untuk menghasilkan bioetanol melalui teknik pengolahan lanjutan. Bioetanol sangat cocok untuk digunakan sebagai bahan bakar kendaraan karena akan cair pada suhu kamar dan dapat ditangani dengan cara yang mirip dengan bahan bakar konvensional. Selanjutnya, alkohol memiliki nilai oktan yang tinggi memungkinkan rasio kompresi mesin tinggi yang meningkatkan efisiensi mesin dan kinerja. Kesesuaian alkohol sebagai bahan bakar kendaraan ditunjukkan oleh penggunaannya sebagai bahan bakar motor balap. Dibandingkan dengan bensin, bahan bakar memiliki kepadatan energi volumetrik rendah yang mengakibatkan kendaraan bioetanol membutuhkan lebih banyak bahan bakar per kilometer (sebanyak 50\%). Bioetanol dapat digunakan baik dalam murni atau bentuk 'hydrous' nya (4\% air berdasarkan volume) di kendaraan khusus, atau sebagai campuran bioetanol-bensin 'anhidrat'.[1]

Sorgum merupakan tanaman serealia yang dapat tumbuh pada berbagai keadaan lingkungan sehingga potensial dikembangkan, khususnya pada lahan marginal beriklim kering di Indonesia. Keunggulan sorgum terletak pada daya adaptasinya yang luas, toleran terhadap kekeringan, produktivitas tinggi, dan lebih tahan terhadap hama dan penyakit dibandingkan dengan tanaman pangan lainnya

Sorgum memiliki potensi hasil yang relatif lebih tinggi walaupun dalam kondisi kering. Bila kelembaban tanah pada saat pertumbuhan bukan merupakan faktor pembatas, hasil sorgum dapat mencapai 7 ton/ha. Pada tabel 1 dapat dilihat perbandingan luas panen tahun 2011-2013 di Indonesia.[2]

Tabel 1.

Perbandingan Luas Panen Tahun 2011-2013 di Indonesia

\begin{tabular}{lc}
\hline \multicolumn{1}{c}{ Provinsi } & Luas Lahan (ha) \\
\hline Sulawesi Selatan & 3405 \\
Sulawesi Tenggara & 4 \\
Nusa Tenggara Timur & 11.415 \\
Nusa Tenggara Barat & 68 \\
Lampung & 25 \\
Jawa Barat & 258 \\
Jawa Tengah & 45 \\
Jawa Timur & 211 \\
\hline \hline
\end{tabular}

Berdasarkan data persebaran sorgum di Indonesia, pabrik bioetanol ini sesuai didirikan di Nusa Tenggara Timur karena sebagai luas lahan terbesar dimana Kabupaten dengan luas lahan terbesar terdapat di Kabupaten Belu [2]. Selain itu tersedianya bahan baku, terdapat suplai air yang cukup 
memadai serta dekat dengan sarana transportasi dan pelabuhan.

Tabel 2.

Standar Nasional Indonesia Kualitas Bioetanol (SNI 7390-2008)

\begin{tabular}{lcc}
\hline \multicolumn{1}{c}{ Parameter } & Unit, Min/Max & Spesifikasi \\
\hline Kadar etanol & $\%$-v,min & 99,5 \\
Kadar methanol & mgL,max & 300 \\
Kadar air & $\%$-v,max & 1 \\
Kadar denaturan & $\%$-V,min & 2 \\
Kadar Cu & Mg/kg,max & 0,1 \\
Keasaman sebagai & mg/L,max & 30 \\
CH ${ }_{3}$ COOH & & 50 \\
Kandungan sulfur & mg/L,max & 5 \\
Tampakan & & $6,5-9$ \\
Getah Suci & Jg/100 ml,max & Jidak ada endapan \\
pH & & 5 \\
\hline \hline
\end{tabular}

Bahan baku pembuatan etanol ini merupakan hasil limbah dari batang sorgum. Hal ini dikarenakan batang sorgum sendiri masih dapat dimanfaatkan prospeknya untuk kebutuhan primer, maka dari itu selain bahan baku ini recycle, limbah batang sorgum juga dapat mengurangi total cost untuk membeli bahan baku untuk dijadikan sebagai etanol. Pada tabel 2 dapat dilihat standar nasional Indonesia kualitas bioetanol (SNI 7390-2008)[3].

\section{URAIAN PENELITIAN}

Berdasarkan tipe-tipe proses, pemilihan proses yang digunakan untuk pembuatan bioetanol dari limbah batang sorgum antara lain : Tahap Pre-Treatment, Tahap Hidrolisis, Tahap Fermentasi dan Tahap Pemurnian [4].

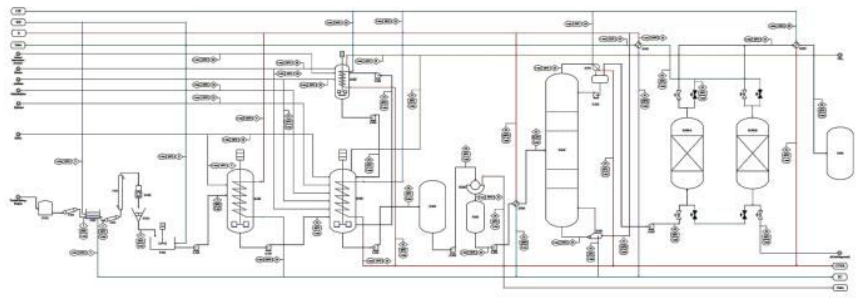

Gambar 1. Process Flow Diagram

Pada awalnya, Sebelum dilakukan pre-treatment, limbah batang sorgum yang akan digunakan sebagai bahan baku proses disimpan di dalam gudang, proses penyimpanan harus kurang dari 6 jam. Limbah batang sorgum dibawa dari gudang melewati belt conveyor menuju bak pencuci untuk mencuci [9]. Batang sorghum kemudian menuju belt conveyor dan bucket elevator sebelum masuk ke rotary knife cutter untuk diiris tipis [9]. Irisan batang sorgum ini dihancurkan sampai halus dengan menggunakan rasper. Batang sorgum yang halus dimasukkan ke dalam tangki mixing. Dalam tangki mixing ditambahkan air untuk mengencerkan hingga kandungan kurang lebih $40 \%$ berat selulosa dan kemudian diaduk sampai homogen [5]. Setelah ditampung pada tangki mixing, maka proses selanjutnya slurry tersebut dimasukkan ke dalam reaktor pre-treatment, untuk dipecah ikatan lignoselulosa yang terkandung dalam limbah batang sorgum menjadi selulosa dengan penambahan $\mathrm{H}_{2} \mathrm{SO}_{4} 2 \%$ [4]. Setelah proses pretreatment kemudian selulosa akan masuk ke reactor SSF untuk proses hidrolisis dengan enzim xylanase untuk mengubah selulosa menjadi glukosa [5]. Kemudian glukosa sebanyak $10 \%$ dari total produk akan diumpan ke reaktor seeding untuk starting fermentasi dengan menggunakan mikroorganisme Kluyveromyces marxianus $0,08 \%$ volume media sebelum akhirnya akan masuk kembali ke reaktor SSF untuk proses fermentasi untuk mengubah glukosa menjadi bioetanol [5]. Setelah keluar dari reaktor SSF, bioetanol hasil proses fermentasi dipisahkan dari padatannya dengan rotary vacuum filter [7] dan kemudian dimurnikan dengan proses distilasi hingga didapatkan bioetanol 95\% [6] hingga akhirnya akan dimurnikan kembali dengan molecular sieve untuk menghasilkan bioetanol 99,5\% [9]

\section{MATERIAL BALANCE}

Berikut ini merupakan hasil perhitungan material balance pabrik bioetanol dari limbah batang sorgum dimana kapasitas feed sebesar $3430 \mathrm{~kg} / \mathrm{jam}$ dan produk yang dihasilkan adalah bioetanol sebesar $347,7 \mathrm{~kg} / \mathrm{jam}$.

\section{ANALISA EKONOMI}

Dari hasil perhitungan pada analisa ekonomi didapatkan Total Cost Investment pabrik ini sebesar Rp 185.026.802.894 dengan bunga per tahun 9,75\%. Selain itu, diperoleh IRR sebesar $10 \%$ dan BEP $42,17 \%$ dimana pengembalian modalnya selama 1,45 tahun. Umur dari pabrik ini diperkirakan 10 tahun dengan masa periode pembangunan 3 tahun dimana operasi pabrik ini 330 hari/tahun.

\section{KESIMPULAN/RINGKASAN}

Berdasarkan analisa ekonomi dengan metode discounted cash flow terhadap factor ekonomi pra desain pabrik bioetanol dari limbah batang sorgum difermentasikan dengan Kluyveomyces marxianus ini, maka diperoleh hasil sebegai berikut :

1. Laju Pengembalian Modal (Rate of Return) sebesar 10\% per tahun. Hal ini menunjukan bahwa ROR yang diperoleh lebih besar dibandingkan dengan nilai I untuk pinjaman modal pada bank dengan tingkat bunga $9,75 \%$ sehingga pabrik layak untuk didirikan. [10]

2. Waktu Pengembalian Modal (Pay Out Time) pabrik ini adalah 1,45 tahun [8]

3. Titik Impas (Break Even Point) adalah 42,17\%. Dari hasil evaluasi secara teknis dan ekonomis, pabrik bioetanol ini sudah memenuhi syarat untuk dilanjutkan ke tingkat perencanaan. Dari segi ekonomi, pra rencana ini telah 
layak didirikan dengan masa konstruksi 3 tahun dan umur pabrik 10 tahun [10]

\section{DAFTAR PUSTAKA}

[1] Aurelio, Marco. Bioethanol. Croatia: Intech

[2] Subagio, Herman. (2013). Pengembangan Produksi Sorgum di Indonesia. Bandung: Seminar Nasional Inovasi Teknologi Pertanian

[3] SNI 7390:2012, Bioetanol Terdenaturasi untuk Gasohol

[4] Choudhary, Jairam. (2016). Thermotolerant Fermenting Yeast for Simultaneous Saccharification Fermentation of Lignocellulosic Biomass. India: Indian Agriculltural Research Institute

[5] Chandel, Anuj Kumar. (2007). Economics and Enviromental Impact of Bioethanol Production Technologies an Appraisal. Malaysia: Universiti Malaysia Sabah.

[6] Ludwig, Ernest E. Applied Process Design Volume 2 (3 $3^{\text {rd }}$ ed) (1997). America: Mc. Graw-Hill

[7] Walas, S. M. (1990). Chemical Process Equipment Selection and Design. Kansas: Butterworth-Heinemann.

[8] Max Peter, K. T. (2004). Plant Design and Economics for Chemical Engineers (5th ed.). Singapura: Mc. Graw-Hill.

[9] Perry, R. H. (1997). Perry's Chemical Engineers' Handbook (7th ed.). (J. O. Don W. Green, Ed.) United States of America: Mc. Graw-Hill.

[10] Robert S. Aries, R. D. (1955). Chemical Engineering Cost Estimation. New York: Mc Graw-Hill Book Company

[11] Sinnott, R. K. (2005). Chemical Engineering Design (Coulson \& Richardson's Chemical Engineering Series (4th) ed., Vol. 6). Oxford: Elsevier Butterworth-Heinemann.

[12] Lloyd E. Brownell, E. H. (1979). Process Equipment Design Vessel Design. New York: John Wiley \& Sons Inc.

[13] Geankoplis, C. J. (2003). Transport Processes and Separation Process Principles (Include Unit Operation) (4th ed.). USA: Pearson Education Inc.

[14] Yaws, C. L. (1999). Chemical Properties Handbook. Texas: Mc GrawHill. 